care issues and a wider range of professional concerns. The paper from Jecker and Self, for example, explores the care-curc debate and the relationship between medicine and nursing, but as an attempt to address wider concerns it is insufficient. There is mention in the introduction of the development of caring ethics, but therc is no real contribution on this theoretical approach.

The book looks impressive and well presented, but first impressions give way to some irritation at the presentation of the content. Many of the chapters have simply been photocopicd from the original journal and then presented as camera ready copy; some of these copies appear not to have been of the highest quality. Each chapter thus has a different appearance, with different fonts, somc in columns and some not. Each page is numbered sequentially throughout the book, but also has the page number of the original journal. The book has a name index, but no subject index, which somcwhat detracts from the book's usefulness as a reference work.

PAUL WAINWRIGHT PHD, MSC, SRN

Senior Lecturer, School of Health Science, University of Wales Swansea

\section{A Good Death: Conversations with East Londoners}

\section{Michael Young and Lesley Cullen, London and New York, Routledge, 1996, 249 pages, $£ 13.99$ (pb).}

The management of bereavement forms a cornerstone of general practice. Not only does it give the doctor the opportunity to be a true family physician but it also allows the practice of the art, as opposed to the science, of medicine.

The practice of the care of the dying is an opportunity to safeguard the physical, emotional and spiritual needs of the dying person. It is during this phase that the doctor-patient relationship may undergo significant development. As a result, the doctor may become part of the extended family and, following the death of the patient, one of the grieving, especially if the relationship with the deceased was memorable or special in some particular way.

Michael Young and Lesley Cullen have written a book that helps us all understand the lives of people as they approach death. W'ritten for both patients and professionals, it informs without hectoring, and suggests improvements in medical and nursing education. Each chapter has an extensive and contemporary bibliography for those wishing to study the subject in greater depth. The authors interviewed fourteen cancer patients and their carers from London's East End over an extended period. The chapters were developed from the themes elucidated using qualitative research techniques and include many relevant ethical considerations. They make the point that cancer usually provides a slow death; patients have time in which to grieve themselves over their loss of health. Their bodics let them down. Just as in health we take our body for granted, so with cancer there is the rumination over the body letting us down. The patients were the experts who shared their experiences with the authors.

This book teaches us that listening to terminally ill patients becomes an education in itself. They have their own narratives to tell. It helps them, and us, to make sense of life and death so that doctoring can become a maturing experience. The role of the medical and nursing professions is to explain, treat and cure where appropriate. Where this is impossible, our role should be in caring, communicating and easing.

Doctors are criticised for their lack of communication skills. Although I felt this was stereotyping, the authors do make the point that times are changing. As we approach the end of the 20th century and enter the new millennium, they agree that more time spent in talking with patients is time well spent; but in a chronically underfunded health service, doctors, as a resource, are in short supply. Time is therefore limited. Patients pay for this by fear, lack of knowledge and apparent lack of caring.

The book also explores the common communicating technique of "telling relatives" and shows how this damages relationships within the family. Doctors would do well to read the chapter on "The doctor". It should be compulsory reading for all professionals who deal with the dying. Not only is consumerism guiding us into new relationships with patients and drawing us away from benign, and not so benign, paternalism, but also new knowledge allows us to consider the moral points which have previously supported our behaviours. Things are beginning to change; new and con- tinuing research is challenging old attitudes and belicfs. As our knowledge of reality improves, so wc can base our practice on better evidence.

The chapter on euthanasia is wellos written. The arguments both for ando against are debated with reference to흐 contemporary thinkers. The rule of $\overline{\overline{\bar{T}}}$ "double effect" is described. These $\overparen{\Phi}$ concepts are once again in the news. The authors make a plea that the ${ }^{\infty}$ common law approach by many doc- $\overrightarrow{0}$ tors needs to be more fully discussed $\overrightarrow{-}$ and debated by experts and legisla- $\vec{\omega}$ tors.

The chapter on bereavement is good review of the subject. Theiv authors make the important point that a "good death" may result in a "poor $\omega$ bereavement". Because of the interde-N pendency of some relationships, the응 survivor may have significant difficulty in coming to terms with the new real- 0 ity. Some of their subjects remained grief-stricken for more than fourteen months following the death of $a \stackrel{\Phi}{-}$ spouse. As professionals we need to be $\vec{\theta}$ accepting of the uniqueness of $\mathrm{ogr} \infty$ patients and allow each of them time to readjust. For some there will be readjustment!

Mention is made of folk beliefs and $\bar{\partial}$ the afterlife. Such beliefs have been held for millennia. They help the $\stackrel{\mathbb{Q}}{Q}$ bereaved to make some sense, and $\vec{\overrightarrow{ }}$ gain control, of the reality of death.

The book ends on a philosophical $\frac{\supset}{\supset}$ note. What are we to make of death and bereavement? Although the person dies, something remains. We have $\bar{B}$ memories, beliefs and concepts but we $\frac{\Phi}{\sigma}$ do not usually have a strong commu- 3 nity in which to embed these ideas. Many of us remain virtually alone in our feelings, apart from friends and neighbours. Community is something 음 much grander which has deteriorated $D$ over time. But we also leave genes which, as they replicate themselves, $N$ could conceivably survive for thou-os sands of years. This sustains us in our $\mathrm{N}$ understanding of an afterlife, which, N stripped of its religious overtones, can be said to form a scientific reality.

Although rather verbose, this book $\frac{0}{0}$ should be read by nurses and doctors $\mathscr{O}$ who see and treat the dying and $T$ bereaved. It challenges us to consider ${ }_{0}$ our own educational needs and assists $\overrightarrow{\mathbb{D}}$ those of us in general practice educa- $\frac{O}{\Phi}$ tion to rise to the challenge of provid- $\varrho$ ing relevant, evidence-based learning. 